\title{
Trichostrongylus and Haemonchus anthelmintic resistance in naturally infected sheep from southern Brazil
}

\author{
VANDERLEI KLAUCK ${ }^{1}$, RAFAEL PAZINATO ${ }^{1}$, LEANDRO S. LOPES ${ }^{2}$, DIEGO C. CUCCO ${ }^{2}$, \\ HORACIO L. DE LIMA ${ }^{1}$, ANDREIA VOLPATO ${ }^{1}$, WILLIAN M. RADAVELLI ${ }^{1}$, \\ LENITA C.M. STEFANI ${ }^{2,3}$ and ALEKSANDRO S. DA SILVA ${ }^{2}$ \\ ${ }^{1}$ Graduação de Zootecnia, Departamento de Zootecnia, Universidade do Estado de Santa Catarina (UDESC), \\ Rua Beloni Trombeta Zanin, 680E, Chapecó, 89815-630 Santa Catarina, SC, Brasil \\ ${ }^{2}$ Departamento de Zootecnia, Universidade do Estado de Santa Catarina (UDESC), \\ Rua Beloni Trombeta Zanin, 680E, Chapecó, 89815-630 Santa Catarina, SC, Brasil \\ ${ }^{3}$ Programa de Pós-Graduação em Ciência Animal, Universidade do Estado de Santa Catarina (UDESC), \\ Avenida Luiz de Camões, 2090, 88520-000 Lages, SC, Brasil
}

Manuscript received on February 19, 2013; accepted for publication on September 9, 2013

\begin{abstract}
The anthelmintic resistance in small ruminants is a common problem and concern worldwide. The aim of this study was to verify anthelmintic treatment efficacy in naturally infected sheep. This study was conducted on nine herds that used the same anthelmintic management for over a year. In each farm, the animals were divided into two groups: untreated control group $(n=5)$ and treated $(n=10)$ according to the number of eggs per gram of feces (EPG). The treatment effect was checked based on EPG results and larval culture performed before treatment and 10 days after treatment. Significant differences were not observed $(P>0.05)$ on EPG results between untreated and treated groups. The coproculture showed that the animals were infected primarily by Haemonchus spp., Trichostrongylus spp., Teladorsagia spp., Cooperia spp. and Oesophagostomum spp. In all farms, anthelmintic resistance by genera Haemonchus and Trichostrongylus was found, but this resistance varied greatly between farms. Haemonchus spp. showed resistance to closantel, levamisole, and albendazole. Trichostrongylus spp. was shown to be resistant to closantel, levamisole, and albendazole. The drugs tested showed to be efficient against the genera Teladorsagia, Cooperia, and Oesophagostomum. Based on these results, we conclude that the anthelmintic resistance to the tested drugs is a problem present in the farms evaluated.
\end{abstract}

Key words: Anthelmintic resistance, albendazole, closantel, levamizol, helminths.

\section{INTRODUCTION}

Gastrointestinal parasites affect sheep production causing economic losses due to weight loss, decreased milk and wool production, and are the leading cause of death among infected untreated animals. Currently, Brazilian livestock has 17.3

Correspondence to: Aleksandro S. da Silva

E- mail: aleksandro_ss@yahoo.com.br million sheep, and the state of Santa Catarina has about 203.000 heads, mainly for meat production (IBGE 2010). Sheep raised under grazing conditions are more susceptible to various parasites and the primary control method is through the use of broadspectrum anthelmintics (Waller 1997). However, the indiscriminate use of these drugs without appropriate association with other methods to fight parasite 
infection has favored the development of helminth resistance to various drugs in the gastrointestinal tract of small ruminants (Morales and Pino 2001).

The development of anthelmintic resistance has increased lately in small ruminants in the Southern Hemisphere, where sheep production takes place primarily in grazing systems (Waller 2003). The main sheep parasite in terms of prevalence and pathogenicity is Haemonchus contortus, but other species should be highlighted such as Trichostrongylus colubriformis. Mixed infections are commonly reported among these animals, mainly by Cooperia spp., Teladorsagia spp., Oesophagostomum spp. and Strongyloides spp. (Ramos et al. 2004). H. contortus is the most important nematode associated to the rapid development of resistance in small ruminants in southern Brazil (Farias et al. 1997), northeastern Brazil (Charles 1989), and in other countries in Latin America (Waller et al. 1996).

Anthelmintic resistance can be defined as a decrease in the efficiency of a drug against the parasite population that is generally susceptible to the drug (Sangster and Gill 1999). According to some researchers, various species of nematodes can develop resistance to a specific anthelmintic (multispecific resistance) or a nematode species to various drugs (multidrug resistance) (Coles and Roush 1992). Resistant parasites are usually in a smaller number in population, but the selection pressure exerted by a given drug favors the increase of resistance among individuals in the same population originally susceptible to the anthelmintic treatment (Lejambre et al. 2000). Given the explanation above this study aims at verifying anthelmintic treatment efficacy in naturally infected sheep from Santa Catarina, southern Brazil.

\section{MATERIALS AND METHODS}

This study surveyed nine farms (farms A to I) located in the western part of the state of Santa Catarina, southern Brazil in a 30-day period, corresponding to the month of May, 2012. First, an interview was conducted to find out about farm management regarding the use of anti-parasitic drugs as well as clinical cases of parasitism and animal mortality. Six of these farms with around 21 to 43 animals each, did not have sheep as their main source of income, but for family consumption only or for small sales purposes. Three other farms had a large herd (between 400 and 1000 sheep), of which two raised sheep for milk production, and one for meat. It was noted that all farms had other animal species; however, the sheep did not share the same pasture area. These farms were chosen because they were using the same drug for over a year, five of which were using the same drug for more than two years. Another requirement for the farm to be included in the study was that the sheep could not have received antiparasitic treatment in the last 30 days.

Among the tests used to detect anthelmintic resistance, the fecal egg count reduction test (FECRT) is the most widely employed. The FECRT is a practical and inexpensive test appropriate for all anthelmintic drugs and only requires technician's ability to count eggs per gram (EPG) of feces (Coles 2005, Veríssimo et al. 2012). Fecal samples from 15 to 20 adult sheep were collected directly from the rectum, stored in identified plastic bags and transported under refrigeration in styrofoam boxes to the laboratory. Stool samples were processed within 48 hours of collection using the McMaster technique with supersaturated sugar solution in order to quantify the number of EPG (Gordon and Whitlock 1939), using 2 grams of feces from each animal. Sheep from each farm were divided into two groups: five animals were used as untreated control $(\mathrm{n}=5)$ and ten animals that were treated with the same anthelmintic drug for more than one year. The groups were formed based on the results of EPG, aiming at homogeneous groups. A pool fecal sample from each group was also collected to perform coproculture under constant humidity and temperature (Roberts and O'Sullivan 1950). 
After this initial analysis, the treatment was carried out with the anthelmintic dose recommended by the manufacturer, on each farm. Sheep from FarmsA and $\mathrm{B}$ were treated with closantel $\left(10 \mathrm{mg} \mathrm{kg}^{-1}\right)$; animals from Farms C and D were treated with levamisole hydrochloride $\left(5 \mathrm{mg} \mathrm{kg}^{-1}\right)$; sheep from Farms E, F, G and $\mathrm{H}$ were treated with albendazole $\left(4 \mathrm{mg} \mathrm{kg}^{-1}\right)$; and Farm I used a combination of albendazole ( $\left.4 \mathrm{mg} \mathrm{kg}^{-1}\right)$ and levamisole $\left(5 \mathrm{mg} \mathrm{kg}^{-1}\right)$. All treatments were carried out orally in a single dose. After 10 days of treatment new samples were collected to perform EPG and larval culture as previously mentioned.

The data were tested for normality and transformed when necessary. EPG data were not normally distributed and were rank-transformed before statistical analysis. EGP mean \pm standard deviations were analyzed by Student's test ( $t$ test) among control and treated groups, and considered significant when $P<0.05$. The anthelmintic efficiency in the FECRT was calculated by the RESO 2.0 program, where the mean arithmetic of EPG for the control group and the group treated by calculating the confidence interval of the mean was used. We considered the existence of anthelmintic resistance reduction when the EPG observed after treatment was less than $95 \%$ and the confidence interval below $90 \%$ as recommended by literature. In this study we did not aim to compare farms, since management, types of parasites and treatments were different.

\section{RESULTS}

Surveyed farms reported the same anthelmintic treatment for more than one year, treating animals at 1-4 month intervals, depending on the season and farm management. Only three farms that had sheep production as their main source of income had an anti-parasite program with treatments every 45 days during hot and rainy seasons. These farms also had reports of helminthiasis (pale mucous membranes and diarrhea) in young and adult animals and mortality in untreated young sheep.
The other farms treated their sheep only when clinical signs appeared, and these farms did not have mortality in adult sheep by nematodes, but there was lamb mortality in four of these farms between October and December 2011. All farms were using antiparasitic only in animals that showed clinical signs. None of the farms used their animals before treatment, and used the same dosage for all individuals, and only four farms were using rotational grazing. Due to the lack of nearby specialized laboratory assistance, parasitological stool examinations were not performed in the last year, even though they continued to use the same anthelmintic treatment as usual.

In the investigated farms a few different genera of helminths were identified, including Haemonchus, Trichostrongylus, Teladorsagia, Cooperia and Oesophagostomum, in which Haemonchus and Trichostrongylus were present in all farms and in greater prevalence (Table I). There was no significant difference $(P>0.05)$ in EPG counts between treated and untreated control groups in all farms tested. Parasitic treatments were unreliable according to highly variable EPG results from treated animals. FECRT values were below 95\% in all farms (Figure 1), which characterizes anthelmintic resistance.

The main parasites that presented resistant to the anthelmintics tested were Haemonchus spp. and Trichostrongylus spp. as shown in Table I. Trichostrongylus resistance to closantel was observed in Farm B, and resistance to Haemonchus and Trichostrongylus was seen in Farm A. Trichostrongylus and Haemonchus resistance to levamisole hydrochloride was also observed in Farms C and D, respectively. All farms that used albendazole showed Haemonchus resistance (Farms E to H) as well as Haemonchus resistance associated with Trichostrongylus resistance in one farm(Farm F). Alow efficiency against Haemonchus and anthelmintic resistance by Trichostrongylus was observed when the drugs albendazole and levamizole were used in combination (Farm I). 
TABLE I

Average number of eggs per gram of feces (EPG) and percentage of helminthes (Haemonchus [HAE],

Trichostrongylus [TRI], Teladorsagia [TEL], Cooperia [COO] and Oesophagostomum [OES]) present in fecal samples from sheep before and after anthelmintic treatment with closantel (Farms A and B), levamisole (Farms

C and D), albendazole (Farms E, F, G and H), and combination of levamisole and albendazole (Farm I).

\begin{tabular}{|c|c|c|c|c|c|c|c|c|c|c|c|c|c|}
\hline \multirow[t]{3}{*}{ Farm } & \multirow[t]{3}{*}{${ }^{+}$Treatment } & \multicolumn{2}{|c|}{ \#Average of EPG/Group } & \multicolumn{10}{|c|}{ Helminths per group (\%) } \\
\hline & & \multirow[t]{2}{*}{ Control } & \multirow[t]{2}{*}{ Treated } & \multicolumn{5}{|c|}{ Control group } & \multicolumn{5}{|c|}{ *Treated group } \\
\hline & & & & HAE & TRI & TEL & COO & OES & HAE & TRI & TEL & COO & OES \\
\hline \multirow{2}{*}{ A } & Before & $1220 \pm 540$ & $1310 \pm 835$ & 58.0 & 38.0 & 0.0 & 3.0 & 1.0 & 54.0 & 42.0 & 0.0 & 2.0 & 2.0 \\
\hline & After & $920 \pm 630$ & $660 \pm 410$ & 50.0 & 46.0 & 0.0 & 4.0 & 0.0 & 64.0 & 36.0 & 0.0 & 0.0 & 0.0 \\
\hline \multirow{2}{*}{ B } & Before & $850 \pm 245$ & $760 \pm 335$ & 10.0 & 71.0 & 19.0 & 0.0 & 0.0 & 6.0 & 80.0 & 14.0 & 0.0 & 0.0 \\
\hline & After & $975 \pm 410$ & $337 \pm 292$ & 5.0 & 75.0 & 20.0 & 0.0 & 0.0 & 0.0 & 100.0 & 0.0 & 0.0 & 0.0 \\
\hline \multirow{2}{*}{$\mathrm{C}$} & Before & $2520 \pm 1045$ & $2060 \pm 1235$ & 34.0 & 66.0 & 0.0 & 0.0 & 0.0 & 28.0 & 72.0 & 0.0 & 0.0 & 0.0 \\
\hline & After & $2725 \pm 2734$ & $440 \pm 230$ & 27.0 & 73.0 & 0.0 & 0.0 & 0.0 & 0.0 & 100.0 & 0.0 & 0.0 & 0.0 \\
\hline \multirow{2}{*}{$\mathrm{D}$} & Before & $870 \pm 385$ & $950 \pm 504$ & 89.0 & 11.0 & 0.0 & 0.0 & 0.0 & 94.0 & 6.0 & 0.0 & 0.0 & 0.0 \\
\hline & After & $805 \pm 375$ & $690 \pm 400$ & 80.0 & 20.0 & 0.0 & 0.0 & 0.0 & 100.0 & 0.0 & 0.0 & 0.0 & 0.0 \\
\hline \multirow{2}{*}{ E } & Before & $210 \pm 165$ & $268 \pm 220$ & 53.0 & 47.0 & 0.0 & 0.0 & 0.0 & 40.0 & 60.0 & 0.0 & 0.0 & 0.0 \\
\hline & After & $257 \pm 180$ & $550 \pm 140$ & 46.0 & 54.0 & 0.0 & 0.0 & 0.0 & 100.0 & 0.0 & 0.0 & 0.0 & 0.0 \\
\hline \multirow{2}{*}{$\mathrm{F}$} & Before & $1700 \pm 835$ & $1550 \pm 1092$ & 81.0 & 19.0 & 0.0 & 0.0 & 0.0 & 90.0 & 10.0 & 0.0 & 0.0 & 0.0 \\
\hline & After & $1750 \pm 980$ & $788 \pm 674$ & 74.0 & 26.0 & 0.0 & 0.0 & 0.0 & 44.0 & 56.0 & 0.0 & 0.0 & 0.0 \\
\hline \multirow{2}{*}{ G } & Before & $200 \pm 100$ & $325 \pm 283$ & 60.0 & 30.0 & 0.0 & 1.0 & 9.0 & 68.0 & 20.0 & 0.0 & 4.0 & 8.0 \\
\hline & After & $226 \pm 173$ & $100 \pm 100$ & 44.0 & 52.0 & 0.0 & 0.0 & 4.0 & 100.0 & 0.0 & 0.0 & 0.0 & 0.0 \\
\hline \multirow{2}{*}{$\mathrm{H}$} & Before & $440 \pm 267$ & $452 \pm 405$ & 50.0 & 42.0 & 8.0 & 0.0 & 0.0 & 54.0 & 44.0 & 2.0 & 0.0 & 0.0 \\
\hline & After & $480 \pm 155$ & $151 \pm 185$ & 41.0 & 54.0 & 5.0 & 0.0 & 0.0 & 96.0 & 4.0 & 0.0 & 0.0 & 0.0 \\
\hline \multirow{2}{*}{ I } & Before & $8090 \pm 5750$ & $7400 \pm 4840$ & 67.0 & 28.0 & 5.0 & 0.0 & 0.0 & 72.0 & 25.0 & 2.0 & 1.0 & 0.0 \\
\hline & After & $7705 \pm 6210$ & $4205 \pm 3204$ & 56.0 & 40.0 & 4.0 & 0.0 & 0.0 & 32.0 & 68.0 & 0.0 & 0.0 & 0.0 \\
\hline
\end{tabular}

\#There was no statistically significant difference $(P>0.05)$ in EPG between treated and untreated control group in each of the farms. ${ }^{+}$The sheep were treated with the dose recommended by the manufacturer, see label.

* In the last column "treated group" in bold presented resistant parasites (i.e. between 4-100\%).

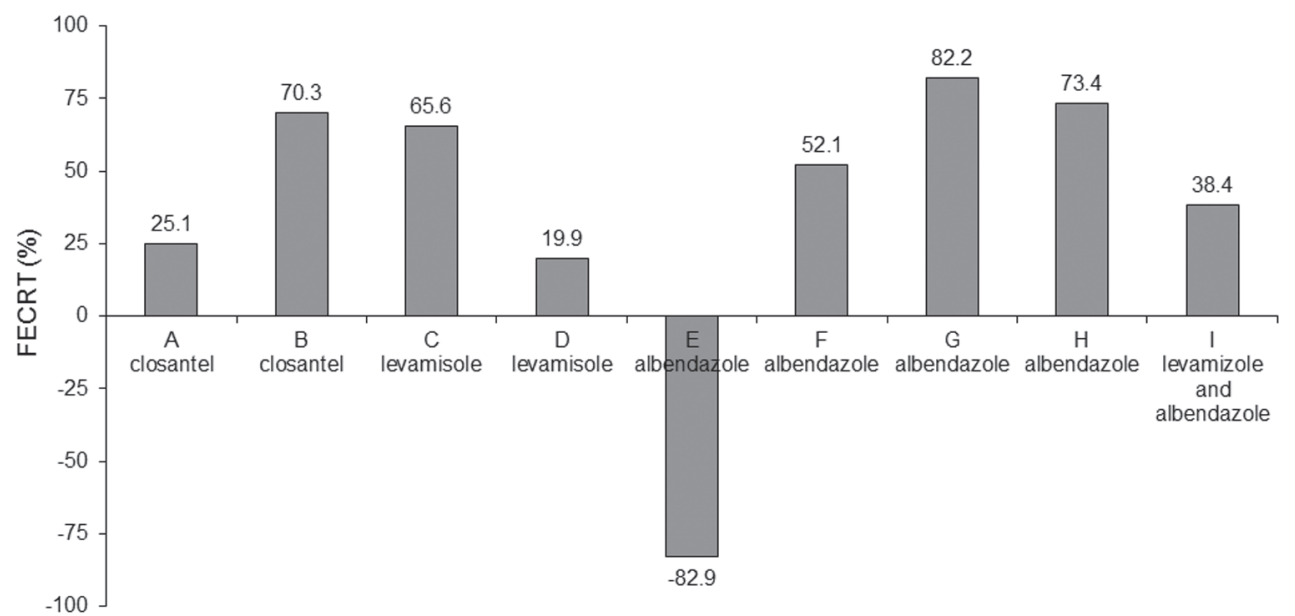

Farms evaluated and anthelmintic treatment used

Figure 1 - The fecal egg count reduction test (FECRT) on farms in western Santa Catarina, when we tested the efficacy of anthelmintics to closantel (Farms A and B), levamisole (Farms C and D), albendazole (Farms E, F, G and $\mathbf{H}$ ) and combination of levamisole and albendazole (Farm I). *FECRT less than $95 \%$ represents the occurrence of anthelmintic resistance. 


\section{DISCUSSION}

Anthelmintic ineffectiveness is a global reality, where drugs that have no record of parasite resistance to helminths from the Trichostrongylidae family, are rare (Coles 2005, Monteiro 2010, Laurenson et al. 2012). In this study, we noted multidrug and multispecies resistance in sheep in the western part of the state of Santa Catarina, a region undiagnosed hitherto for helminthic resistance. In Brazil, the development of parasites is benefited by the tropical climate, which is conducive to the free-living stages of parasites such as eggs and larvae present in the environment (Monteiro 2010). In general, sheep helminths develop strong resistance to the anti-parasitic drugs commercially available. This resistance is a matter of evolution and adaptation of the parasite to survive. This process can occur in a short period of time or take a long time, depending primarily on the type of drug management. The everyday use, without technical guidance and incorrect anthelmintic treatment, is the main cause for the process of resistance, among other factors (Monteiro 2010, Elsheikha and Khan 2011). However, the control of nematode parasites cannot be viewed in isolation, because frequent feeding, age and physiological state are important factors which favor parasite control. Many authors argue that the main way to control helminthiasis is related to strategies designed to control the spread of parasites in the environment, but recent studies have shown that to attain this goal it is better to select resistant animals to parasites (Laurenson et al. 2012).

In this study, it was noted that most farms used the same anthelmintic drug on short intervals during a long period of time (1 to 4 years), without knowing its true effectiveness. All farms investigated in this study presented problems with resistance to one or more parasites, therefore it is a multispecies resistance with different degrees between farms varying accordingly to the type of drug used, similar to what was recently observed in the state of São Paulo, Brazil (Veríssimo et al. 2012).
In the study, we recorded the prevalence mainly by helminth from the Trichostrongylidae family, similar to that observed in other Brazilian states (Kawano et al. 2001, Ramos et al. 2004, Monteiro 2010, Veríssimo et al. 2012) and other countries (Elsheikha and Khan 2011, Papadopoulos et al. 2012). In the region studied, there was a predominance of parasites from the genus Haemonchus and Trichostrongylus, which were also parasites with diagnosis of resistance. In some farms, the genus Teladorsagia appeared prevalent, unlike the genera Cooperia and Oesophagostomum. This study found no resistance to the tested drugs by Teladorsagia, Cooperia and Oesophagostomum, different from what is reported in other Brazilian states (SczesnyMoraes et al. 2010, Veríssimo et al. 2012).

The closantel belongs to the class of salicylanides that acts uncoupling oxidative phosphorylation in the parasite. The results observed for closantel should take into account that this anthelmintic is specifically targeted at Haemonchus sp. and it is not effective against many other helminths (Dash 1986). In this study, this drug was investigated in two farms, and in both farms drug resistance by Trichostrongylus sp. was detected, but only on those farms that had drug resistance by Haemonchus sp. However, closantel treatment for Cooperia, Oesophagostomum and Teladorsagia was effective in controlling these helminths, although this drug is not recommended to treat these worms (Dash 1986). Parasite resistance and/or low susceptibility of Trichostrongylidae family to closantel has been described in different continents, as well as Latin America (Nari et al. 1996, Ramos et al. 2002, Rosalinski-Moraes et al. 1992, Sczesny-Moraes et al. 2010, Veríssimo et al. 2012).

Another drug tested in our study was levamisole, an imidazothiazole, which is administered to control nematodes in ruminants (Gong et al. 2006). This anti-parasitic is widely used in Brazil for dairy cattle because the manufacturers claim that the product has no withdrawal period. However, 
recent studies suggest that levamisole can leave residues in milk, even after the industrial process (Power et al. 2012). We mention this because one of the studied farms that used levamisole to control gastrointestinal nematodes in sheep is also a major milk and milk products producer. Two farms that used levamisole had nematode resistance, one of them by Haemonchus spp. and the other by Trichostrongylus spp., which is not a surprise (Nari et al. 1996, Ramos et al. 2002, Rosalinski-Moraes et al. 1992, Sczesny-Moraes et al. 2010, Veríssimo et al. 2012).

Albendazole, a broad-spectrum anti-parasitic drug, has been used in four farms, which acts by inhibiting the absorption of glucose by the parasite preventing the production of ATP (Elsheikha and Khan 2011). In all farms, anthelmintic resistance to the genera Trichostrongylus and Haemonchus was observed. The resistance of helminths in relation to albendazole has been registered for several years (Ramos et al. 2002, Molento 2004, RosalinskiMoraes et al. 1992, Sczesny-Moraes et al. 2010, Veríssimo et al. 2012).

Due to individual resistance of some active principles, many industries have invested in the combination of drugs. Nevertheless, the outcome is not favorable as found in this study, where the combination of albendazole and levamisole had no effect on FECRT, and Haemonchus and Trichostrongylus resistance was observed. Multiple anthelmintic resistance in nematodes from small ruminants are widespread in some places, especially in tropical countries (Voigt et al. 2012). We believe that the use of drugs combined, uncontrollably and without orientation, can aggravate the problem of parasitic resistance.

According to some researchers, it is essential to understand the mechanisms involving drug resistance so that alternative treatment strategies can be developed (Waller 1997, James et al. 2009). Changes in genes or in gene expression in response to drugs, enable the organism to survive treatment and might reflect evolution in a toxic environment in which drug resistance leads to 'survival of the fittest' (James et al. 2009). The drugs investigated in this study are often used and consequently presented a broad level of resistance by parasites from the Trichostrongylidae family. As already mentioned, the resistance is a difficult process to be avoided, being a matter of adaptation of the parasite and thus, surviving. However, errors related to the management and use of incorrect treatments can accelerate this process of resistance, which probably occurred in the analyzed farms which presented no differences between treated and untreated animals regarding FECRT results.

Based on our findings we conclude that farms in the western region of Santa Catarina have anthelmintic resistance to closantel, albendazole, and levamizole; i.e. the FECRT was less than $95 \%$ in all farms investigated. The anthelmintic resistance of the genera Haemonchus and Trichostrongylus was observed in the farms. In contrast, no resistance was observed to Teladorsagia spp., Cooperia spp. and Oesophagostomum spp. in this study.

\section{ACKNOWLEDGMENTS}

We thank Amanda B. Almeida, Julia Rossett, and Assis E.A. Bongoski from the Animal Science Department/UDESC for their assistance in collecting and processing all samples.

\section{RESUMO}

A resistência de anti-helmínticos em pequenos ruminantes é um problema comum e de interesse em todo o mundo. O objetivo deste estudo foi verificar a eficácia do tratamento anti-helmíntico em ovinos naturalmente infectados. Este estudo foi realizado em nove rebanhos que utilizaram o mesmo anti-helmíntico por mais de um ano. Em cada fazenda, os animais foram divididos em dois grupos: grupo controle, não tratado $(\mathrm{n}=5)$ e tratados $(\mathrm{n}=10)$ com base no número de ovos por grama nas fezes (OPG). O efeito do tratamento foi avaliado com base nos resultados de OPG e coprocultura 
realizados antes do tratamento e 10 dias após. Não foi observada diferença significativa $(P>0,05)$ entre os grupos tratados e não tratados em relação aos resultados do OPG. A coprocultura demonstrou que os animais estavam infectados principalmente por Haemonchus spp., Trichostrongylus spp., Teladorsagia spp., Cooperia spp. e Oesophagostomum spp. Em todas as fazendas foi encontrada resistência anti-helmíntica dos helmintos Haemonchus spp. e Trichostrongylus spp., mas esta resistência variou muito entre fazendas. Haemonchus spp. demonstrou ser resistente ao closantel, levamisol e albendazol. Trichostrongylus spp. demonstrou ser resistente ao levamisole, closantel e albendazol. As drogas testadas mostraram-se eficientes contra Teladorsagia spp., Cooperia spp. e Oesophagostomum spp. Com base nesses resultados, podemos concluir que a resistência anti-helmíntica às drogas testadas é um problema presente nas fazendas avaliadas.

Palavras-chave: resistência anti-helmíntica, albendazol, closantel, levamizole, helmintos.

\section{REFERENCES}

CHARLES TP. 1989. Seasonal prevalence of gastrointestinal nematodes of goats in Pernambuco State, Brazil. Vet Parasitol 30: 335-343.

COLES GC. 2005. Anthelmintic resistance, looking to the future: A UK perspective. Res Vet Sci 78: 99-108.

COLES GC AND RoUSH RT. 1992. Slowing the spread of anthehnintic resistant nematodes of sheep and goats in the United Kingdom. Vet Rec 130: 505-510.

DASH KM. 1986. Control of helminthosis in lambs by strategic treatment with closantel and broad-spectrum anthelmintics. Aust Vet J 63: 47-48.

ELSHEIKHA HM AND KHAN NA. 2011. Essentials of Veterinary Parasitology. Loughborough: Caister Academic Press, 221 p.

FARIAS MT, BORDIN EL, FORBES AB AND NEWCOMB KA. 1997. A survey on resistance to anthelmintic in sheep studs farms of southern Brazil. Vet Parasitol 72: 209-214.

Gong FC, WU DX, CAO Z AND HE XC. 2006. A fluorescence enhancement-based sensor using glycosylated metalloporphyrin as a recognition element for levamisole assay. Bios Bioelect 22: 423-428.

GORDON HM AND WHITLOCK HV. 1939. A new technique for counting nematode eggs in sheep faeces. J Sci Ind Res 12: 50-52. A new technique for counting nematode eggs in sheep faeces.

IBGE - InSTITUTO BRASILEIRo DE GEOGRAFIA E ESTATÍstiCA. 2010. Pesquisa Pecuária Municipal. Disponível em $<$ http:// www.ibge.gov.br> Accessed in July, ${ }^{\text {rd }}, 2012$.
James CE, Hudson AL AND Davey MW. 2009. Drug resistance mechanisms in helminths: is it survival of the fittest? Trends Parasitol 25: 328-335.

KAWANO EL, YAmamura MH AND Ribeiro ELA. 2001. Efeito do tratamento com anti-helmíntico em cordeiros naturalmente infectados com helmintos gastrintestinais sobre os parâmetros hematológicos, ganho de peso e qualidade da carcaça. Acta Vet Sci 29: 113-121.

LAURENSON YCSM, KYRIAZAKIS I, FORBES AB AND BISHOP SC. 2012. Exploration of the epidemiological consequences of resistance to gastro-intestinal parasitism and grazing management of sheep through a mathematical model. Vet Parasitol 189: 238-249.

LEJAMBRE L, GILL J, LENANE J AND BAKER P. 2000. Inheritance of ivermectin resistance in Haemonchus contortus. Int $\mathrm{J}$ Parasitol 30: 105-111.

Molento MB. 2004. Sustainable worm management. Vet Rec 171: 95-96.

Monteiro SG. 2010. Parasitologia Veterinária. São Paulo: Roca, $356 \mathrm{p}$.

Morales G And PINO LA. 2001. Drogas anti-helmínticas sobre estrongilos digestivos em ovinos estabulados. Rev Cient Vet Trop 26: 147-158.

Nari A, Salles J, Gil A, Waller PJ AND Hansen JW. 1996. The prevalence of anthelmintic resistance in nematode parasites of sheep in Southern Latin America: Uruguay. Vet Parasitol 62: 213-222.

Papadopoulos E, Gallidis E AND Ptochos S. 2012. Anthelmintic resistance in sheep in Europe: A selected review. Vet Parasitol 198: 85-88.

Power C, SAyers R, O'Brien B, Bloemhoff Y, Danaher M, FUREY A AND JORDAN K. 2012. Partitioning of nitroxynil, oxyclozanide and levamisole residues from milk to cream, skim milk and skim milk powder. Int J Dairy Technol 65: 1-4.

Ramos CI, Bellato V, Ávila VS, Coutinho GC AND Souza AP. 2002. Resistência de parasitos gastrintestinais de ovinos a alguns anti-helmínticos no Estado de Santa Catarina, Brasil. Ciênc Rural 32: 473-477.

Ramos CI, Bellato V, Souza AP, Avila VS, Coutinho GC AND DALAGNOL CA. 2004. Epidemiologia das helmintoses gastrintestinais de ovinos no Planalto Catarinense. Ciênc Rural 34: 1889-1895.

ROBERTS FHS AND O'SULLIVAN JP. 1950. Methods for egg counts and larval cultures for strongyles infesting the gastrointestinal tract of cattle. Aust J Agric Res 1: 99-102.

Rosalinski-Moraes F, MORETTO LH, BRESOLIN WS, GABRIELLI I, KAFER L, ZANCHET IK, COLES G AND ROUSH R. 1992. Slowing the spread of anthelmintic resistance nematodes of sheep and goats in the United Kingdom. Vet Rec 130: 505-510.

SANGSTER NCAND GILL J. 1999. Pharmacology of anthelmintic resistance. Parasitol Today 15: 141-146.

Sczesny-Moraes EA, Bianchin I, DA Silva KF, CATto JBR AND PAIVA F. 2010. Anthelmintic resistance of gastrointestinal nematodes in sheep, Mato Grosso do Sul, Brazil. Pesq Vet Bras 30: 229-236. 
VERÍSSIMO CJ ET AL. 2012. Multidrug and multispecies resistance in sheep flocks from São Paulo State, Brazil Vet Parasitol 187: 209-216.

Voigt AK, Scheuerleb M And Hamelb D. 2012. Triple anthelmintic resistance in Trichostrongylus spp. in a German sheep flock. Small Rumin Res 106: 30-32.

WALler PJ. 1997. Anthelmintic Resistance. Vet Parasitol 72: $391-4127$.
WALlER PJ. 2003. Global perspectives on nematode parasite control in ruminant livestock: the need to adopt alternatives to chemotherapy, with emphasis on biological control. Anim Health Res Rev 4: 35-43.

Waller PJ, EcheVarria F, EdDI C, MACIEl S, NARI A AND HANSEN JW. 1996. The prevalence of anthelmintic resistance in nematode parasites of sheep in Southern Latin America: General overview. Vet Parasitol 62: 181-187. 